Intersections

Canadian Journal of Music

Revue canadienne de musique
Intersections CANADAN TOURAA OP NUSIC

\title{
John Haines. 2010. Medieval Song in Romance Languages. Cambridge: Cambridge University Press. 318 pp. ISBN 9780521765749
}

\section{Jennifer Bain}

Volume 31, numéro 2, 2011

URI : https://id.erudit.org/iderudit/1013217ar

DOI : https://doi.org/10.7202/1013217ar

Aller au sommaire du numéro

Éditeur(s)

Canadian University Music Society / Société de musique des universités canadiennes

ISSN

1911-0146 (imprimé)

1918-512X (numérique)

Découvrir la revue

Citer ce compte rendu

Bain, J. (2011). Compte rendu de [John Haines. 2010. Medieval Song in Romance Languages. Cambridge: Cambridge University Press. 318 pp. ISBN

9780521765749]. Intersections, 31(2), 113-117. https://doi.org/10.7202/1013217ar

All Rights Reserved (C Canadian University Music Society / Société de musique des universités canadiennes, 2012
Ce document est protégé par la loi sur le droit d'auteur. L'utilisation des services d'Érudit (y compris la reproduction) est assujettie à sa politique d'utilisation que vous pouvez consulter en ligne.

https://apropos.erudit.org/fr/usagers/politique-dutilisation/ 


\section{BOOK REVIEWS / RECENSIONS}

John Haines. 2010. Medieval Song in Romance Languages. Cambridge: Cambridge University Press. 318 pp. ISBN 9780521765749.

Medieval Song in Romance Languages by John Haines is one of the most engagingly written books of musicology I have read in the last few years. Its readability is evident already in the table of contents, which includes rather quirky and useful descriptions of each chapter, such as this one on the love song: "In which it is argued that love songs were commonly sung in Romance languages well before the troubadours, that women sang them, and that modern historians, influenced by the medieval prejudices mentioned earlier, have obscured the number and importance of these festive love songs" (v). The project itself is admirable and almost wildly ambitious: Haines endeavours to uncover the history of vernacular song from 500 to 1200 , of which only a dozen pieces are extant in notated form. Arguing against the perception that vernacular song began with the troubadours and trouvères, Haines substantiates the existence of such a repertory through scattered references in various kinds of literature. Philologists seem to generally agree that "proto-Romance" languages themselves existed by the fifth century (15), and already in the sixth century Boethius in his Consolation of Philosophy refers to the "vernacular music of our hearth" (17), suggesting "some form of Vulgar Latin or Proto-Romance" (17-18). According to Cuthbert, biographer of the Venerable Bede who died in 735, Bede engaged in vernacular song as well, singing in Anglo-Saxon (18), and Charlemagne, according to Einhard the Frank, "wrote and commissioned for posterity vernacular (barbara) and very ancient songs in which were sung the deeds and wars of the ancient kings" (19).

The greatest strength of Haines's book is in his identification of what actually qualifies as Romance song from 500 to 1200 . Looking beyond the limited notational traces of the repertory, Haines has collected and uncovered many written descriptions of a vernacular practice from this period, including lament, love song, epic song, devotional song, and lullaby. Despite the source limitations of such a project, Haines has provided us with an incredibly valuable resource by including not only transcriptions (some modern, where appropriate), editions of the texts, translations, and editorial comments for each of the twelve notated songs he does locate, but also facing page, photographic, black-and-white facsimiles of the original manuscripts-a gift for musicologists and performers alike (195-296).

The main thrust for Haines in this study is to argue for an acknowledgement by musicologists of this vernacular practice. Throughout, he grapples 
with the issue of how to talk about a musical practice that has little physical record in musical notation or recording, an issue already faced for several decades by those of us interested in the recovery of historical women's involvement in music. Scholars of the history of women and music have often set aside the idea of "authorship" and have focused instead on other kinds of musical activities in which women have engaged, such as performance, domestic music-making, and patronage. Already in 1948 "amateur" musicologist Sophie Drinker, well ahead of the professional musicologists of her day, developed a social and cultural history of music, centring on the activities of women. ${ }^{1}$ Haines's study is valuable, however, in making a case for this kind of research in medieval musicology in particular, a discipline that has been focused since its nineteenth-century inception on monumental musical manuscripts and on individual, heroic composer figures (144-56). It is not an entirely new concept, however, even in medieval musicology: Christopher Page, for example, has been bringing various literary sources of musical commentary to our attention since the 198 os, while Keith Polk has provided us with ample evidence about un-notated, instrumental music practices. ${ }^{2}$ More generally in musicology, of course, this seismic shift is readily apparent particularly in the study of popular music, which is by no means rare and often involves the analysis of practice rather than text.

Another recurrent thread in the book for Haines is the repeated condemnation by male clerics of vernacular practices and female musical activities. His sleuth work in this regard is admirable as he traces these remarks through medieval sermons, an underutilized source of musical commentary. The sampling of these remarks included in the Appendix in both Latin and English translation $(162-71)$ is particularly useful, but-much like the surviving repertory-still rather scant, making it sometimes difficult to accept his generalizations about the repertoire. One thing that Haines does not do in this book is theorize throughout about either the language used in the condemnations or the musical practices the authors denigrate, as he acknowledges (tacitly) in his note "to the reader" at the beginning of the volume. He describes the project as being a highly personal one and stipulates that he "ceased to write about medieval song for this or that audience, academic or otherwise; and began writing - the reader has a right to know-mainly for myself" (4). But since so much literature has come out in the last few decades on class, gender, and women's musical practices, Haines's material in this book prompts us to look at some broader issues and ask deeper questions.

In his chapter on the lament, Haines delves into literature on medieval funeral practices, including performances by professional female lamenters. He provides scathing remarks by Latin writers about these activities (38) and argues persuasively that as a discipline we have been too dependent on formal records of funeral practices, focusing on Latin liturgical books, which would

1 Drinker's work was pioneering and has been exceptionally influential, particularly for its methodology. There are, unfortunately, certain gaps in her scholarship and frequent errors; I have found, for example, five errors in a single paragraph on Hildegard $(1948,200)$.

2 See, for example, Page (1989) and Polk (1992). 
apply only to church funerals (39-40), and accepting unquestioningly the admonitions of learned writers that Christians should rejoice rather than weep on these occasions (42). As Haines demonstrates, most people in the Middle Ages could not afford a church burial (41), so these documents will tell us nothing about other practices, the practices-I think this needs emphasizing-of the lower classes. We might also ask whether these Christian, clerical admonitions are tinged with religious condemnation, when, for example, the Council of Arles decries "diabolical songs" in $524 \mathrm{CE}$, indicating that they are "foreign to Christian religion" (163).

When in the same chapter Haines brings up very briefly the topic of effeminacy (46), he could dig much deeper. He reports that men must avoid "sounding effeminate," but he does not interrogate exactly what this means in that time and place. What elements of performance made men's voices sometimes sound effeminate? What musical characteristics did these clerics view as feminine and masculine? Were there other, non-musical activities denigrated in this same literature for also being effeminate? Along the same lines, we can ask deeper questions when considering the lament specifically. Haines briefly links women's lamenting traditions to both incantations and magic (50), but I would like to know more about the women in medieval culture who are actually singing laments. Are they old? Young? Peasant women? Urban women? Is lamenting associated only with funerals, or is it also, as it is in other cultures and time periods, associated with other significant life passages such as weddings? Ethnomusicologist Elizabeth Tolbert, for example, studying lamenting traditions in twentieth-century eastern Finland and the former Soviet Karelia tries to figure out why it is not only a female practice in this particular culture but also carried out exclusively by women who are past their child-bearing years. She argues that the lament simultaneously embodies nature (associated with femininity and manifested by weeping in performance), and culture (associated with masculinity and manifested by complicated and elaborate texts), ${ }^{3}$ and that the lamenter holds a powerful position in the community as a mediator between the world of the living and the world of the dead. ${ }^{4}$ We might well ask whether or not professional lamenters in medieval society were similarly viewed as powerful by their contemporaries, and if so, was it this power that the learned writers object to? These questions, of course, are much easier to ask of a living community than of scant documentation from a thousand years ago, but they are questions worth asking.

Those scholars working in the area of masculinity studies might well be drawn to Haines's chapter on epic song, the domain of male singers, using his material to construct competing images of medieval masculinity, particularly in contrast with the portrayals of Christ in the chapter on devotional song. Similarly, his chapter on the love-song-sung by women and associated with festivities such as weddings but condemned for its lascivious lyrics and lewd gestures-offers us the opportunity to draw parallels between the medieval

3 See Tolbert (1990, 45).

4 Ibid., 41. 
genre and musical practices in other cultures and time periods. Judith Cohen, for example, describes a similar female repertory of Judeo-Spanish wedding songs, which frequently include erotic themes, ${ }^{5}$ while the film Monsoon Wedding (2001), which features a modern Hindu Punjabi family in New Delhi, vividly demonstrates a lewd wedding song sung by a group of dancing and hand-clapping women during a henna-painting scene. ${ }^{6}$ Again, when Haines relates the medieval association of prostitutes with singing (64-65), we can contextualize those remarks against the backdrop of recent musicological literature on the long association of perceived hyper-sexuality and women's public involvement in music-making, ranging from various courtesan traditions, to the anonymous but public slurs on the character of seventeenth-century composer and singer Barbara Strozzi, to the modern marketing techniques of female musicians across many genres of music, including the revealing $C D$ covers of bond, the all-female British crossover string quartet. ${ }^{7}$

Perhaps the most important question to ask of this early vernacular repertory, but impossible to answer, is, what did it sound like? At the end of his first chapter on song, Haines suggests that the "performance of Romance song ... more often than not had little to do with the notated specimens" he has found (33); Romance song was transmitted orally, and with so few notated examples found "mostly in the margins of a dozen liturgical or learned manuscripts in the Latin tongue" (23), we cannot be at all secure in how representative they are of what must have been a vast repertoire. It is thus curious that towards the end of his account of devotional song Haines concludes that "songs in praise of Christ and of Mary, and songs of every-man and of every-woman, in all likelihood sounded remarkably alike" (143). This conclusion seems to be based on melodic similarities, but as he has demonstrated throughout, song is so much more than simply melody; aside from obvious textual differences from one song to another, the song traditions he has described can encompass vastly different approaches to vocal style and declamation, incorporation of bodily gestures and dance, rhythm and tempo. To put it in a modern context, I can certainly hear the borrowed melody of J. S. Bach's, O Haupt voll Blut und Wunden (itself borrowed from Hans Leo Hassler's Mein G'müth ist mir verwirret from 1601) in Paul Simon's American Tune, but I would never venture to say that the songs "sound remarkably alike" when I hear them performed. ${ }^{8}$ One version, sung in a reverberant church or concert hall, in four parts, a cappella or accompanied by organ, with pious words describing Christ's suffering on the cross bears little relation (aside from the melody) to the other, sung as an amplified solo by a New York Jew, accompanied by acoustic guitar, with the ambience of a studio or a live performance, the text emphasizing disappointment with the American dream, but also resignation, and the knowledge that another day shall dawn. While I cannot know truly or even remotely what vernacular song sounded like in the Christian West from 500 to 1200, I think

5 Cohen $(1987,57)$.

6 See Monsoon Wedding.

7 See, for example, Feldman and Gordon (2006), Rosand (1986, 172), and Mok (2002).

8 For further history of the tune, see Blankenburg and Panetta, "Hassler." 
it is safe to venture that it did not all sound alike, even if the same or similar melodies were used.

But for what this book does offer-an overview of the evidence of Romance song long before the troubadours and trouvères, a range of genres of vernacular song from this time period, a sense of distinction between male and female musical practices, and the facsimiles and editions of the complete extant repertory of vernacular song in Romance languages before $1200-$ it is a stimulating read.

\section{WORKs Cited}

Blankenburg, Walter and Vincent J. Panetta. N.d. Grove Music Online. Oxford Music Online, s.v. "Hassler." http://www.oxfordmusiconline.com.

Cohen, Judith R. 1987. "Ya Salió de la Mar': Judeo-Spanish Wedding Songs among Moroccan Jews in Canada." In Women and Music in Cross-Cultural Perspective, ed. Ellen Koskoff, 55-67. New York: Greenwood.

Drinker, Sophie. 1948. Music and Women: The Story of Women in Their Relation to Music. New York: Coward-McCann.

Feldman, Martha, and Bonnie Gordon, eds. 2006. The Courtesan's Arts: CrossCultural Perspectives. New York: Oxford University Press.

Mok, Davena. 2002. "Sex in the Symphony." Time, 22 March.

Monsoon Wedding. 2002. Directed by Mira Nair. Universal City, CA: Universal Studios.

Page, Christopher. 1989. The Owl and the Nightingale: Musical Life and Ideas in France 1100-1300. London: Dent.

Polk, Keith. 1992. German Instrumental Music of the Late Middle Ages: Players, Patrons, and Performance Practice. New York: Cambridge University Press.

Rosand, Ellen. 1986. “The Voice of Barbara Strozzi.” In Women Making Music: The Western Art Tradition, 1150-1950, ed. Jane Bowers and Judith Tick, 16890. Urbana, IL: University of Chicago Press.

Tolbert, Elizabeth. 1990. "Magico-Religious Power and Gender in the Karelian Lament." In Music, Gender and Culture, ed. Marcia Herndon and Susanne Ziegler, 41-56. Wilhelmshaven: Florian Noetzel Verlag.

JENNIFER BAIN

Sten Ingelf. Learn from the Masters: Classical Harmony. Hjärup, Sweden: Sting Musik, 2010. 222 pp. (paper), 193 pp. on DVD. ${ }^{1}$ ISBN 91-971133-5-2.

Unlike North American textbooks meant for four semesters of core music theory study, this course in harmony is geared less towards learning to analyze music than expanding composing and arranging skills such as are needed for work in film, television, and other media. A study of tertian harmony for

1 Printable PDFs. Additional files on the DVD require iTunes or QuickTime, and free download of Finale NotePad. 